\title{
KARAKTERISASI FISIKOKIMIA IKAN BAGE (MAKANAN TRADISIONAL SUMBAWA) MENGGUNAKAN OVEN PENGERING
}

\author{
Rhestu Isworo ${ }^{1^{\star},}{ }^{2}$ Anni Nuraisyah \\ ${ }^{1 *}$ Fakultas Teknologi Pertanian Universitas Teknologi Sumbawa \\ 2 Fakultas Teknologi Pertanian Universitas Teknologi Sumbawa \\ *Corresponding Author email: rhestu.isworo@uts.ac.id,anni.nuraisyah@uts.ac.id
}

\begin{tabular}{|c|c|}
\hline & Abstrak \\
\hline $\begin{array}{l}\text { Diterima : } \\
\text { Bulan Januari } \\
2021\end{array}$ & $\begin{array}{l}\text { Produksi ikan lemuru di Sumbawa mengalami kenaikan dan salah satu produk olahannya } \\
\text { yang terkenal adalah ikan bage. Ikan bage ini diolah dengan proses penggaraman dan } \\
\text { pengasaman, kemudian dikeringkan dan digoreng. Permintaan masyarakat Sumbawa } \\
\text { yang ingin membawa oleh-oleh khas ikan bage ini keluar daerah sudah banyak. Oleh } \\
\text { karena itu dalam penelitian ini dilakukan proses pengeringan terkontrol menggunakan }\end{array}$ \\
\hline $\begin{array}{l}\text { Diterbitkan: } \\
\text { Bulan Februari } \\
2021\end{array}$ & $\begin{array}{l}\text { oven, dan diharapkan menjadi solusi untuk memperbaiki mutu ikan bage secara } \\
\text { fisikokimia dan mikrobiologis. Hasil penelitian menunjukkan ikan lemuru segar memiliki } \\
\text { rata-rata kadar air sebesar } 86 \% \text {, kadar protein } 19,8 \% \text {, kadar lemak } 6,1 \% \text {. Kandungan air } \\
\text { ikan bage tertinggi terdapat pada perlakuan dengan suhu } 50^{\circ} \mathrm{C} \text { selama } 2 \text { jam }(56,33 \%)\end{array}$ \\
\hline $\begin{array}{l}\text { Keyword: } \\
\text { ikan bage, oven } \\
\text { pengering, suhu, } \\
\text { fisikokimia }\end{array}$ & $\begin{array}{l}\text { sedangkan kadar air terendah terdapat pada pengeringan } 4 \text { jam dengan suhu } 60^{\circ} \mathrm{C} \\
(28,41 \%) \text {. Nilai uji TPC tertinggi didapatkan pada ikan bage pengeringan suhu } 50^{\circ} \mathrm{C} \\
\text { selama } 2 \text { jam yaitu sebesar } 21000 \mathrm{CFU} / \mathrm{gr}\left(2,1 \times 10^{4} \mathrm{CFU} / \mathrm{gr}\right) \text {. }\end{array}$ \\
\hline
\end{tabular}

\section{PENDAHULUAN}

Tangkapan ikan lemuru (Sardinella lemuru) di Sumbawa mengalami peningkatan, data tahun 2012-2016 berturut-turut adalah 960,33 ton; 1.092,31 ton; $2.265,20$ ton; $2.348,80$ ton; $2.405,60$ ton (1). Berdasarkan data produksi ikan lemuru tersebut, Sumbawa memiliki makanan khas olahan ikan yang cukup terkenal yaitu ikan bage.

Dalam bahasa Sumbawa bage artinya asam. Proses pembuatannya yaitu, penggaraman dan pengasaman, kemudian dikeringkan dan digoreng. Masyarakat Sumbawa menyukai ikan bage ini karena rasa dan teksturnya sangat berbeda dengan ikan asin. Olahan ikan bage banyak ditemukan di pasar tradisional Sumbawa atau pun di warungwarung tempat makan.

Berdasarkan rencana pembangunan ekonomi BAPPEDA Kabupaten Sumbawa, yang telah disampaikan dalam Seminar Inovasi Pemasaran IKM Sumbawa pada bulan Mei 2018 disebutkan bahwa kuliner khas Sumbawa sangat prospektif untuk meningkatkan nilai tambah komoditi unggulan daerah (2). Termasuk dalam hal ini kuliner ikan bage yang telah dikelola secara home industri oleh masyarakat desa Ai Bari, Moyo Utara. Berdasarkan wawancara dengan salah seorang warga desa Ai Bari, pemasaran ikan bage sejauh ini hanya di dalam wilayah Sumbawa. Sementara permintaan masyarakat Sumbawa yang tinggal di luar daerah dan ingin membawa oleh-oleh khas ikan bage tersebut sudah banyak. Faktor penyebab tidak dapat memenuhi permintaan pasar ke luar Sumbawa karena umur simpan ikan bage sangat rendah (mudah busuk).

Tidak seperti ikan asin, ikan bage hanya mampu disimpan dalam waktu tiga hari. Hal ini dikarenakan proses pengeringan dilakukan tradisional \pm 5 jam di bawah sinar matahari sehingga tekstur ikan bage masih tergolong lunak. Cita rasa yang khas inilah yang menyebabkan ikan bage banyak diminati banyak kalangan. Namun di sisi lain pengeringan tersebut berpotensi munculnya kontaminasi mikroorganisme. Perbaikan kualitas produk salah satunya dengan penerapan teknologi proses yang lebih bersih dan higienis. Salah satu alternatifnya dengan pengeringan oven. Tujuan dari pengeringan adalah mengurangi kadar air bahan sampai batas dimana mikroorganisme dan kegiatan enzim yang dapat menyebabkan pembusukan akan terhenti (3). Proses pengeringan mengakibatkan produk mengalami perubahan warna, tekstur, flavor dan aroma. Proses pengeringan ini dipengaruhi oleh suhu, kelembapan udara lingkungan, kecepatan aliran udara pengering, kandungan air yang diinginkan, energi pengeringan dan kapasitas pengeringan (4).

Proses pengeringan yang terkontrol menggunakan oven diharapkan menjadi solusi untuk memperbaiki kualitas ikan bage yang mudah busuk, sehingga dapat dijadikan oleh-oleh khas daerah Sumbawa. Penggunaan suhu tinggi dalam pengeringan dapat meningkatkan biaya produksi dan perubahan biokimia produk. Dalam rangka peningkatan mutu ikan bage yang dikeringkan dengan oven pengering perlu dikaji karakteristik 
kimia, dan mikrobiologis. Mutu ikan bage dapat ditinjau dari karakteristik kimia berupa eksplorasi komposisi kimia (protein, lemak, kadar air, karbohidrat, abu. Karakteristik mikrobiologis menunjukkan adanya kontaminasi bakteri atau tidak.

\section{LANDASAN TEORI}

\section{Sardinella lemuru}

Ikan lemuru (Sardinella lemuru) merupakan jenis ikan pelagis kecil yang banyak dijumpai di perairan Indonesia. Ada dua jenis ikan lemuru yang penting secara ekonomis yaitu Sardinella sirm dan Sardinella longiceps. Daerah penyebaran jenis sardinella sirm terutama di laut Jawa, sedangkan Sardinella longiceps didapatkan dalam jumlah banyak di selat Bali (5). Ikan lemuru memiliki ukuran dan berat maksimum sebesar 21-23 $\mathrm{cm}$ dan $200 \mathrm{~g}$ dan mampu hidup selama 1 tahun (6). Ciri-ciri fisik dari ikan lemuru antara lain: Warna badan biru kehijauan pada bagian atas (punggung), putih keperakan pada bagian bawah. Sirip berwarna abu-abu kekuningan. Warna sirip ekor kehitaman demikian juga pada ujung moncongnya. Pada bagian atas tertutup insang sampai pangkal ekor terdapat sebaris bulatan hitam sebanyak 10-20 buah (7).

Komposisi lemuru (Sardinella lemuru) per 100 gram adalah sebagai berikut: air 76 gram, protein 20 gram, lemak 3 gram, Ca $20 \mathrm{mg}$, fosfor $100 \mathrm{mg}$, Fe $1 \mathrm{mg}$, Vitamin A $100 \mathrm{mg}$, vitamin B1 $0,05 \mathrm{mg}(8)$

\section{Pembusukkan pada ikan}

Banyak bahan makanan yang mudah busuk atau tidak tahan lama sehingga terbatasnya lama penyimpanan dan daerah pemasarannya tidak begitu luas. Salah satu dari bahan makanan tersebut adalah ikan. Oleh sebab itu dilakukan pengawetan makanan, yang bertujuan untuk mempertahankan kualitas suatu makanan selama mungkin dengan cara menghambat atau menghentikan sama sekali penyebab kemunduran mutu (pembusukan) maupun penyebab kerusakan makanan (misalnya aktivitas enzim, mikroorganisme, atau oksidasi oksigen) agar makanan tersebut tetap dalam kondisi yang baik (9).

Salah satu faktor penentu kualitas ikan ialah kesegarannya. Pada produksi hasil laut perubahan kualitas dari segi rasa, bau, tekstur, dan warna dapat terjadi akibat pertumbuhan bakteri. Perubahan kualitas tersebut kecepatannya tergantung dari kadar bakteri awal, kondisi penyimpanan, suhu, kelembaban dan tekanan atmosfir. Produk hasil laut bersifat lebih mudah terdekomposisi dibandingkan produk berprotein tinggi lainnya. Hal disebabkan karena: (1) Beberapa produk hasil laut mengandung kadar osmoregulator tinggi dalam bentuk non protein nitrogen seperti trimetil amin, urea, asam amino dan lain sebagainya yang merupakan media yang baik untuk pertumbuhan bakteri. (2) Produksi hasil laut dipanen dari air yang dingin sehingga flora bakteri tidak mudah dihambat oleh perlakuan suhu dingin dibanding flora hewan atau tanaman. Keamanan produksi hasil laut terutama tergantung dari kemungkinan tercemar mikrobia patogen, atau disebabkan oleh histamin akibat proses penanganan yang kurang tepat (10).

\section{Proses pengeringan \\ Pada umumnya bahan pangan yang dikeringkan akan mengalami pencoklatan} (browning) yang disebabkan oleh reaksi-reaksi nonenzimatik. Pengeringan menyebabkan kadar air bahan pangan menjadi rendah yang juga akan menyebabkan zat-zat yang terdapat pada bahan pangan seperti protein, lemak, karbohidrat dan mineral akan lebih terkontaminasi. Vitamin-vitamin yang terdapat dalam bahan pangan yang dikeringkan akan mengalami penurunan mutu, hal ini disebabkan karena ada beberapa vitamin yang tidak tahan terhadap suhu tinggi. Proses pengeringan yang berlangsung pada suhu tinggi akan menyebabkan terjadinya case hardening yaitu bagian permukanaan bahan pangan sudah kering sekali bahkan mengeras sedangkan bagian dalamnya masih basah (11).

Terdapat berbagai metode dalam pengeringan yaitu antara lain pengeringan dengan sinar matahari langsung, pengeringan dengan oven dan kering angin. Pengeringan dengan matahari langsung merupakan proses pengeringan yang paling ekonomis dan paling mudah dilakukan, akan tetapi darisegi kualitas alat pengering buatan (oven) akan memberikan roduk yang lebih baik. Sinar ultra violet dari matahari juga menimbulkan kerusakan pada kandungan kimia bahan yang dikeringkan (12).

\section{a. Pengeringan dengan sinar matahari}

Pengeringan dengan sinar matahari sering disebut juga sebagai pengeringan alami. Pengeringan matahari merupakan salah satu metode pengeringan tradisional, karena menggunakan panas yang berasal dari sinar matahari langsung. Pengeringan ini sangat rentan terhadap resiko kontaminasi lingkungan, sehingga bahan yang akan dikeringkan harus dilindungi dari serangan serangga-serangga dan sebaiknya ditutup pada malam hari. Pengeringan matahari juga sangat tergantung pada iklim dengan matahari yang panas dan udara atmosfer yang kering (13).

b. Pengeringan dengan oven

Pengeringan oven merupakan alternatif pengeringan matahari. Tetapi metode pengeringan ini membutuhkan sedikit biaya investasi. Pengeringan oven dapat melindungi bahan pangan dari seranggaserangga dan debu serta tidak tergantung pada cuaca. Pengeringan dengan menggunakan oven tidak disarankan untuk pengeringan bahan pangan 
karena sulit untuk mengkontrol suhu rendah dan pangan yang dikeringkan lebih rentan hangus (14). Keuntungan pengeringan dengan oven yaitu tidak tergantung cuaca, kapasitas pengeringan dapat dipilih sesuai dengan yang diperlukan, tidak memerlukan tempat yang luas dan kondisi pengeringan dapat dikontrol (15).

\section{Proses penggaraman}

Proses penggaraman dengan sistem penggaraman basah adalah menggunakan larutan garam sebagai media untuk merendam ikan. Larutan garam akan mengisap cairan tubuh ikan (sehingga konsentrasinya menurun) dan ion-ion garam akan segera masuk ke dalam tubuh ikan (16).

Prinsip pengawetan ikan bage merupakan kombinasi penambahan garam, asam dan pengeringan. Dalam jumlah yang cukup, garam dan asam dapat mencegah terjadinya autolisis, yaitu kerusakan ikan disebabkan oleh enzim-enzim yang terdapat pada ikan dan mencegah terjadinya pembusukkan oleh jasad renik. Selain karena garam, ikan bage menjadi awet karena perlakuan pengeringan.

Proses penggaraman ikan dapat dilakukan dengan tiga cara yaitu :

a. Penggaraman kering (dry salting)

Penggaraman kering dapat digunakan baik untuk ikan yang berukuran besar maupun kecil. Penggaraman ini menggunakan garam berbentuk kristal. Ikan yang akan diolah ditaburi garam lalu disusun secara berlapis-lapis, setiap lapisan ikan diselingi lapisan garam. Selanjutnya lapisan garam akan menyerap keluar cairan di dalam tubuh ikan, sehingga kristal garam berubah menjadi larutan garam yang dapat merendam seluruh lapisan ikan.

\section{b. Penggaraman basah (wet salting)}

Proses penggaraman dengan sistem ini menggunakan larutan garam sebagai media untuk merendam ikan. Larutan garam akan mengisap cairan tubuh ikan (sehingga konsentrasinya menurun) dan ion-ion garam akan segera masuk ke dalam tubuh ikan.

\section{c. Kench salting}

Penggaraman ikan dengan cara ini hampir serupa dengan penggaraman kering. Bedanya, metode ini tidak menggunakan bak kedap air. Ikan hanya ditumpuk dengan menggunakan keranjang. Untuk mencegah supaya ikan tidak dikerumuni oleh lalat, hendaknya seluruh permukaan ikan ditutup dengan lapisan garam.

\section{MATODE PENELITIAN}

Alat dan Bahan
Alat yang akan digunakan adalah
timbangan, wadah/baskom, oven, gelas beker,

cawan porselen, desikator, tang penjepit, neraca analitik, labu kjeldahl, labu takar, kompor destruksi, perangkat destilator, lemari asam, erlenmeyer, pipet ukur, kertas saring, alat ekstraksi soxlet, pendingin tegak, penangas air, labu penampung, stomacher, cawan petri, pipet dan inkubator. Bahan yang digunakan dalam penelitian ini adalah ikan lemuru, garam, penyedap rasa, asam jawa, air, K2SO4, $\mathrm{CuSO} 4, \mathrm{H} 2 \mathrm{SO} 4$ pekat, $\mathrm{H} 3 \mathrm{BO} 33 \%, \mathrm{NaOH} 40 \%$, $\mathrm{H} 2 \mathrm{SO} 40.1 \mathrm{~N}$, Aquades, larutan indikator, Buffer Phospate, media PCA, $\mathrm{HCl}$ dan kloroform.

\section{Prosedur Penelitian}

Prosedur penelitian yang dilakukan adalah: 1. Persiapan dan karakterisasi lemuru Persiapan bahan yang dilakukan yaitu sortasi, pencucian, penirisan, dan penghancuran bawang merah segar. Setelah itu dilakukan karakterisasi fisikokimia dan mikrobiologi dari ikan lemuru. Data ini digunakan sebagai data awal sebelum diproses menjadi ikan bage.

2. Pembuatan ikan bage

Ikan lemuru utuh yang masih segar dibersihkan sisik dan jeroannya. Setelah itu, direndam dalam larutan garam selama 1 jam. Hasil perendaman dicelupkan ke dalam larutan asam yang kental. Setelah itu ikan ditiriskan dan dimasukkan kedalam oven pengering. Tahap akhir dari penelitian ini yaitu dilakukan karakterisasi.

Penelitian ini menggunakan Rancangan Acak Lengkap (RAL) dengan menggunakan dua faktor. Faktor pertama yaitu suhu pengeringan $50{ }^{\circ} \mathrm{C}$ (A), dan $60^{\circ} \mathrm{C}$ (B). Faktor kedua yaitu lama waktu pengeringan 2 jam, 3 jam dan 4 jam $(2,3,4)$. Hasil penelitian akan dianalisa dengan menggunakan uji ANOVA. Setiap perlakuan diulang sebanyak 3 kali ulangan, jadi dalam penelitian ini terdapat 18 unit percobaan. Jika terdapat perbedaan nyata, maka dilanjut uji Duncan dengan taraf signifikan $5 \%$. Pengolahan data dilakukan menggunakan aplikasi SPSS.

\section{HASIL DAN PEMBAHASAN}

\section{Karakterisasi ikan lemuru segar}

Dengan metode AOAC (2005), hasil

karakterisasi awal ikan lemuru sebagai berikut:

Tabel 1. Data Uji Kimia Ikan Lemuru

\begin{tabular}{|l|c|c|c|c|}
\hline Pengujian & Ul 1 & Ul 2 & Ul 3 & Rata-rata \\
\hline Kadar air (\%) & 85 & 84 & 87 & 86 \\
\hline Kadar protein (\%) & 19,6 & 19,5 & 20,3 & 19,8 \\
\hline Kadar lemak (\%) & 5,9 & 5,8 & 6,66 & 6,1 \\
\hline
\end{tabular}

Berdasarkan Tabel 1. di atas dapat diketahui bahwa ikan lemuru segar memiliki rata-rata kadar air sebesar $86 \%$, kadar protein 19,8\%, kadar lemak $6,1 \%$. 


\section{Kadar Air Ikan Bage}

Nilai kadar air dapat dilihat pada Gambar 1.

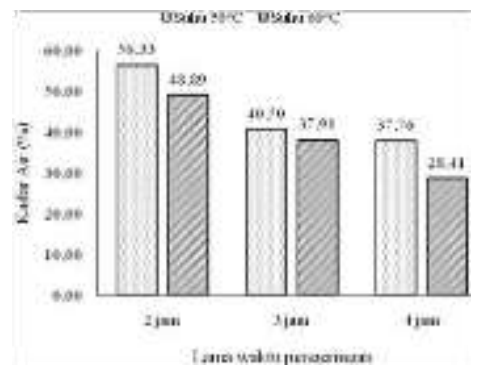

Gambar 1. Grafik kadar air ikan bage perlakuan suhu dan waktu pengeringan

Berdasarkan Gambar 1 dapat diketahui kadar air ikan bage mengalami perbedaan pada perlakuan suhu $50^{\circ} \mathrm{C}$ dan $60^{\circ} \mathrm{C}$. Semakin tinggi suhu pengovenan, nilai kadar air menunjukkan angka lebih rendah. Semakin lama waktu pengovenan dari 2 jam sampai 4 jam menunjukkan nilai kadar air semakin menurun.

Air merupakan komponen penting dalam bahan pangan termasuk dalam ikan bage. Keberadaan air dapat mempengaruhi penampakan, tekstur, serta flavour suatu bahan pangan tersebut. Selain itu, kandungan air dalam bahan pangan menentukan acceptability, kesegaran dan daya tahan bahan tersebut (17). Kadar air merupakan salah satu sifat kimia dari bahan yang menunjukkan banyaknya air yang terkandung di dalam bahan pangan. Menurut (18), menyatakan bahwa air merupakan komponen terbanyak yang terdapat di dalam daging ikan. Jadi dapat disimpulkan semakin tinggi kadar airnya kemungkinan bahan akan mengalami kerusakan semakin cepat, terutama berkaitan dengan kualitas mikrobiologisnya. Semakin rendah jumlah kadar air, semakin awet bahan pangan tersebut.

Hasil penelitian ikan bage pada berbagai kondisi suhu dan waktu pengovenan (Gambar 1) yaitu ikan bage pengeringan suhu $50^{\circ} \mathrm{C}$ memiliki kadar air tertinggi pada waktu pengeringan 2 jam $(56,33 \%)$, sedangkan kadar air terendah pada pengeringan selama 4 jam $(37,76 \%)$. Pada suhu $60^{\circ} \mathrm{C}$ diperoleh kadar air tertinggi pada perlakuan pengeringan selama 2 jam $(48,89 \%)$ sedangkan kadar air terendah pada pengeringan 4 jam $(28,41 \%)$. Berdasarkan hasil perhitungan diatas dapat disimpulkan bahwa kandungan air ikan bage tertinggi terdapat pada perlakuan dengan suhu $50^{\circ} \mathrm{C}$ selama 2 jam $(56,33 \%)$ sedangkan kadar air terendah terdapat pada pengeringan 4 jam dengan suhu $60^{\circ} \mathrm{C}(28,41 \%)$.

Penurunan kadar air ini terus berlangsung dengan semakin lamanya waktu yang digunakan selama proses pegeringan hingga waktu 4 jam. Selain waktu, suhu juga berpengaruh terhadap kandungan air pada ikan bage. Semakin tinggi suhu dan lamanya waktu pengeringan yang diberikan, memberikan pengaruh yang sangat besar terhadap kecepatan perpindahan air. Semakin tinggi suhu pengeringan maka semakin cepat terjadi penguapan, sehingga kandungan air di dalam bahan semakin rendah (19).

Semakin tinggi suhu dan kecepatan aliran udara pengeringan makin cepat pula proses pengeringan berlangsung (20). Makin tinggi suhu udara pengering, makin besar energi panas yang dibawa udara sehingga makin banyak jumlah massa cairan yang diuapkan dari permukaan bahan yang dikeringkan. Jika kecepatan aliran udara pengering makin tinggi maka makin cepat massa uap air yang dipindahkan dari bahan ke atmosfer. Waktu pengeringan 4 jam merupakan perlakuan efektif untuk menurunkan kadar air pada ikan bage. Pengeringan dengan oven jelas memperlihatkan bahwa jumlah kehilangan air meningkat seiring dengan meningkatnya suhu pengeringan (21). Beberapa literatur lain menyebutkan pengovenan suhu $60^{\circ} \mathrm{C}$ dapat menghasilkan karakteristik kimiawi terbaik khususnya pada produk ikan lele dumbo (22).

\section{Total Plate Count (TPC)}

Total Plate Count (TPC) adalah pengujian untuk mengetahui jumlah mikroorganisme yang tumbuh pada suatu sampel. Organisme yang tumbuh jenis mikroorganisme aerobik dan mesofilik yang tumbuh dalam suhu $20-40^{\circ} \mathrm{C}$ baik itu dapat berupa bakteri, khamir, dan kapang aerobik yang tumbuh pada media padat/agar. Seluruh patogen maupun yang non patogen juga dapat dalam perhitungan TPC. Sehingga adanya jumlah mikroorganisme akan menunjukkan kualitas mikrobiologis bahan pangan yang diujikan, apakah mudah terkontaminasi mikroorganisme atau tidak. Hasil perhitungan uji TPC pada ikan bage sebagai berikut:

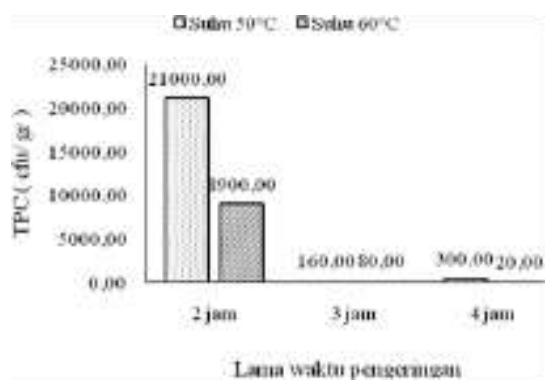

Gambar 2. Grafik perhitungan TPC ikan bage dengan perlakuan suhu dan waktu pengeringan

Berdasarkan Gambar 2 dapat diketahui bahwa nilai uji TPC tertinggi didapatkan pada ikan 
bage pengeringan suhu $50^{\circ} \mathrm{C}$ selama 2 jam yaitu sebesar $21000 \mathrm{CFU} / \mathrm{gr}\left(2,1 \times 10^{4} \mathrm{CFU} / \mathrm{gr}\right)$. Nilai TPC terendah diketahui pada sampel ikan bage pengeringan suhu $60^{\circ} \mathrm{C}$ adalah $20 \mathrm{CFU} / \mathrm{gr}(2,0 \times 101$ CFU/gr). Semakin tinggi suhu dan lama pengeringan menunjukkan data TPC ikan bage semakin menurun. Semakin banyak jumlah air yang diuapkan selama pengeringan, maka jumlah mikroorganisme yang tumbuh pada sampel akan semakin sedikit. Hal ini mengakibatkan daya awet bahan atau umur simpang bahan akan semakin lebih lama. Sebaliknya jika kandungan air di dalam bahan pangan masih tinggi, kemungkinan dijadikan tempat hidup mikroorganisme akan semakin banyak. Dampaknya bahan pangan tersebut akan mudah rusak atau mengalami pembusukan.

Penelitian ikan bage ini menjawab permasalahan yang ada di masyarakat Sumbawa yang selama ini berdasarkan fakta di lapangan umur simpan ikan bage hanya mampu bertahan selama 3 hari pada penyimpanan suhu ruang. Ikan bage akan bertahan selama 1 minggu jika disimpan dalam suhu pendingin.

Nilai TPC ini dapat dijadikan asumsi untuk pendugaan umur simpan ikan bage. Berdasarkan penelitian pada ikan teri asin, penyimpanan hingga 3 bulan diketahui jumlah TPC terhitungnya 1,7 $\mathrm{x}$ 102 CFU/gr (23). Nilai tersebut lebih banyak jika dibandingkan dengan sampel pada ikan bage pengeringan suhu $60^{\circ} \mathrm{C}$ selama 4 jam $(2,0 \times 101$ $\mathrm{CFU} / \mathrm{gr}$ ). Oleh sebab itu, suhu pengeringan $60^{\circ} \mathrm{C}$ selama 4 jam sangat memungkinkan menjadikan ikan bage memiliki umur simpan lebih lama dari 1 pekan. Perlu dilakukan pengujian umur simpan ikan bage dari hasil pengeringan terbaik.

\section{PENUTUP}

\section{Kesimpulan}

Hasil penelitian menunjukkan ikan lemuru segar memiliki rata-rata kadar air sebesar $86 \%$, kadar protein 19,8\%, kadar lemak 6,1\%. Kandungan air ikan bage tertinggi terdapat pada perlakuan dengan suhu $50^{\circ} \mathrm{C}$ selama 2 jam $(56,33 \%)$ sedangkan kadar air terendah terdapat pada pengeringan 4 jam dengan suhu $60^{\circ} \mathrm{C}(28,41 \%)$. Nilai uji TPC tertinggi didapatkan pada ikan bage pengeringan suhu $50^{\circ} \mathrm{C}$ selama 2 jam yaitu sebesar $21000 \mathrm{CFU} / \mathrm{gr}\left(2,1 \times 10^{4} \mathrm{CFU} / \mathrm{gr}\right)$.

\section{REFERENSI}

1. BPS. 2017. Kabupaten Sumbawa Dalam Angka 2017. Sumbawa: BPS Kabupaten Sumbawa.

2. BAPEDDA Sumbawa. 2018. Rencana Pembangunan Ekonomi Kabupaten Sumbawa. http://sumbawakab.go.id

3. Hasibuan, Rosdaneli. 2005. Proses Pengeringan. Program Studi Teknik Kimia Fakultas Teknik Sumatera Utara.
4. Setyoko Bambang, Senen, Seno Darmanto. 2008. Pengeringan Ikan Teri Dengan Sistem Vakum dan Paksa. Edisi XI, No. 1 Februari 2008.

5. Rasyid, A. 2001. Isolasi Asam Lemak Tak Jenuh Majemuk Omega-3 dari Ikan Lemuru (sardinella sp). Prosiding Seminar Riptek Kelautan Nasional. Jakarta.

6. Hay, A. 2010. Sardinella Lemuru.Scaly Mackerel from Sydney Fish Market. http://australianmuseum.net.au/image/ScalyMackerel-Sardinella-lemuru. Tanggal akses 22 November 2011.

7. Hendrasaputra, D. 2008. Optimasi Proses Kristalisasi Urea pada Pembuatan Konsentrat Asam Lemak Omega-3 dari Minyak Hasil Samping Penepungan ikan Lemuru (Sardinella longiceps). Skripsi. Jurusan Teknologi Hasil Pertanian. Universitas Brawijaya. Malang.

8. Poedjiadi, T. Supriyanti. 2009. Dasar-Dasar Biokimia. Universitas Indonesia (UI-Press), Jakarta.

9. Afrianto, E. dan E. Liviawaty. 2011. Pengawetan dan pengolahan ikan. Kanisius. Yogyakarta

10. Wijaya RA, Koeshendrajana S. 2009.Kajian Excess Capacity Pengelolaan Perikanan Lemuru di Selat Bali. Balai Besar Riset Sosial Ekonomi Kelautan dan Perikanan.Badan Riset Kelautan dan Perikanan. Departemen Kelautan dan Perikanan.

11. Nurdjannah, N., Hoerudin. 2008. Pengaruh Perendaman Dalam Asam Organik Dan Metoda Pengeringan Terhadap Mutu Lada Hijau Kering. Bul. Littro. Vol. XIX No.2 Hal 181-196.

12. Purnomo, H. 1995. Aktivitas Air dan Peranannya dalam Pengawet Pangan. UIPress. Jakarta.

13. Fardiaz. S. (1989) Mikrobiologi Pangan. Bogor. Institut Pertanian Bogor.

14. Fellow, PJ. 2000. Food Processing Technology, Principle and Practice. CRC Pres, Boca Raton, Boston, New York, Washington.

15. Widodo, Hendriadi. 2004. Perbandingan Kinerja Mesin Pengering Jagung Tipe Bak Datar Model Segi Empat dan Silinder. Jurnal Enginering Pertanian, Badan Penelitian dan Pengembangan Pertanian, Vol. 2 No.1.

16. Syahrudin. 2013. Pengaruh Penggaraman Terhadap Protein Ikan Layang (Decapterus rucell). Jurnal Calyptra Vol.2 No.1.

17. Winarno. 2004. Kimia Pangan dan Gizi. PT. 
Gramedia Pustaka Utama. Jakarta.

18. Hadiwiyoto. 1993. Teknologi Pengolahan Hasil Perikanan. Liberty. Yogyakarta.

19. Winarno. 2002. Ilmu Pangan dan Gizi. PT. Gramedia Pustaka Utama. Jakarta

20. Rachmawan, O. 2001. Pengeringan, Pendinginan dan Pengemasan Komoditas Pertanian. Buletin Departemen Pendidikan Nasional. Jakarta.

21. Asri, N,D. 2009. Efek Perbedaan Teknik Pengeringan terhadap Kualitas, Fermentabilitas, dan Kecernaan Hay Daun Rami (Boehmeria nivea L Gaud). Skripsi.
Departemen Ilmu Nutrisi dan Teknologi Pakan.Fakultas Peternakan. Institut Pertanian Bogor.

22. Yuniarti, N., D. Syamssuwida dan A. Aminah. 2007. Pengaruh penurunan kadar air terhadap perubahan fisiologi dan kandungan biokimia benih eboni (Diospyros celebica Bahk.). Jurnal Penelitian Hutan Tanaman. Edisi Agustus Vol. 5, No. 3, hal 191-198. Balai Pembenihan. Teknologi Pembenihan Bogor. Bogor.

23. Muchtadi, TR, dan F, Ayustaningwarno. 2010. Teknologi Proses Pengolahan Pangan. Alfabeta. Bandung. 